\title{
Mouse pancreatic islet macrophages use locally released ATP to monitor beta cell activity
}

\author{
Jonathan R. Weitz ${ }^{1,2}$ • Madina Makhmutova ${ }^{1,3}$ • Joana Almaça ${ }^{1}$ - Julia Stertmann ${ }^{4,5,6}$. \\ Kristie Aamodt $^{7}$ - Marcela Brissova $^{8} \cdot$ Stephan Speier $^{4,5,6} \cdot$ Rayner Rodriguez-Diaz $^{1}$. \\ Alejandro Caicedo ${ }^{1,2,3,9}$
}

Received: 14 February 2017 / Accepted: 14 July 2017 /Published online: 7 September 2017

(C) Springer-Verlag GmbH Germany 2017

\begin{abstract}
Aims/hypothesis Tissue-resident macrophages sense the microenvironment and respond by producing signals that act locally to maintain a stable tissue state. It is now known that pancreatic islets contain their own unique resident macrophages, which have been shown to promote proliferation of the insulin-secreting beta cell. However, it is unclear how beta cells communicate with islet-resident macrophages. Here we hypothesised that islet macrophages sense changes in islet activity by detecting signals derived from beta cells.

Methods To investigate how islet-resident macrophages respond to cues from the microenvironment, we generated mice expressing a genetically encoded $\mathrm{Ca}^{2+}$ indicator in myeloid cells. We produced living pancreatic slices from these mice
\end{abstract}

Electronic supplementary material The online version of this article (https://doi.org/10.1007/s00125-017-4416-y) contains peer-reviewed but unedited supplementary material, which is available to authorised users.

Rayner Rodriguez-Diaz

rayner_rodriguez@yahoo.com

Alejandro Caicedo

acaicedo@med.miami.edu

1 Division of Endocrinology, Diabetes and Metabolism, Department of Medicine, University of Miami Miller School of Medicine, 1580 NW 10th Ave, Miami, FL 33136, USA

2 Molecular Cell and Developmental Biology, University of Miami Miller School of Medicine, Miami, FL, USA

3 Program in Neuroscience, University of Miami Miller School of Medicine, Miami, FL, USA and used them to monitor macrophage responses to stimulation of acinar, neural and endocrine cells.

Results Islet-resident macrophages expressed functional purinergic receptors, making them exquisite sensors of interstitial ATP levels. Indeed, islet-resident macrophages responded selectively to ATP released locally from beta cells that were physiologically activated with high levels of glucose. Because ATP is co-released with insulin and is exclusively secreted by beta cells, the activation of purinergic receptors on resident macrophages facilitates their awareness of beta cell secretory activity.

Conclusions/interpretation Our results indicate that islet macrophages detect ATP as a proxy signal for the activation state of beta cells. Sensing beta cell activity may allow macro-
$4 \quad$ Paul Langerhans Institute Dresden (PLID) of Helmholtz Center Munich at the University Clinic Carl Gustav Carus of Technische Universität Dresden, Helmholtz Zentrum München, Neuherberg, Germany

5 DFG-Center for Regenerative Therapies Dresden (CRTD), Faculty of Medicine, Technische Universität Dresden, Dresden, Germany

6 German Center for Diabetes Research (DZD), München-Neuherberg, Germany

7 Department of Molecular Physiology and Biophysics, Vanderbilt University Medical Center, Nashville, TN, USA

8 Division of Diabetes, Endocrinology, and Metabolism, Department of Medicine, Vanderbilt University Medical Center, Nashville, TN, USA

9 Department of Physiology and Biophysics, Miller School of Medicine, University of Miami, Miami, FL, USA 
phages to adjust the secretion of factors to promote a stable islet composition and size.

Keywords ATP · Beta cell · Calcium imaging · Macrophage · Pancreas $\cdot$ Purinergic $\cdot$ Tissue slice

$\begin{array}{ll}\text { Abbreviations } \\ {\left[\mathrm{Ca}^{2+}\right]_{i}} & \text { Intracellular free } \mathrm{Ca}^{2+} \text { concentration } \\ \text { ATP } \gamma \mathrm{S} & \text { Adenosine 5'-(3-thiotriphosphate) } \\ \text { F1 } & \text { First filial generation } \\ \text { GABA } & \gamma \text {-Aminobutyric acid } \\ \text { GFP } & \text { Green fluorescent protein } \\ \text { IBA1 } & \text { Ionised calcium-binding adapter molecule 1 } \\ \text { VNUT } & \text { Vesicular nucleotide transporter } \\ \text { TRPV1 } & \text { Transient receptor potential cation channel } \\ & \text { subfamily V member 1 }\end{array}$

\section{Introduction}

Glucose homeostasis is maintained through hormone secretion from the pancreatic islet. Insulin secretion from beta cells involves the co-release of ATP and serotonin [1, 2], which are potent stimulators of immune cells. Thus, as a by-product of hormone secretion, islet endocrine cells may activate and interact with the local population of immune cells. In response, local immune cells such as resident macrophages may provide homeostatic support. Resident macrophages in other organs (e.g. Kupffer cells, Langerhans cells, microglia) are specialised to perform tissue-specific functions needed for tissue stability [3-5]. In mice that lack islet macrophages, islets show defects in development and decreased beta cell mass [6]. The mechanisms leading to this dysfunction have not been explored, although it is now known that macrophages promote beta cell proliferation [7, 8]. These findings suggest that endocrine and immune cells interact in the islet to maintain tissue homeostasis, although the signalling mechanisms remain mostly unknown.

The role of macrophages in the islet has been studied mainly under stressful conditions (e.g. in diabetes, obesity and regeneration models) in which they contribute to inflammation and disease progression, but also promote beta cell regeneration. These studies provide information about the role of islet macrophages in the context of responses associated with inflammation and autoimmunity. By contrast, little is known about the function of the islet-resident macrophage in the normal state. Only recently have islet-resident macrophages been characterised, based on embryonic origin and on classical immunological markers [9, 10]. Resident macrophages of other tissues can sense hypoxia, hyperosmolarity, metabolic stress or extracellular matrix components to induce tissue-specific behaviours that promote local homeostasis [11]. It is still unclear, however, what aspects of the islet microenvironment are monitored by resident macrophages under normal physiological conditions.

Because macrophages exert trophic effects on beta cells [7, $8,12]$, we hypothesised that to adjust the production of signals such as growth factors, islet macrophages must monitor the functional state of beta cells. Testing this hypothesis requires studying resident macrophages in a preparation in which cellular relationships are preserved. While the physiology of resident macrophages has been studied in tissue slices of organs such as the brain [13], there has not been an equivalent study of pancreas macrophages. To investigate the signals that activate islet-resident macrophages locally, we adapted a method using pancreas tissue slices for in situ imaging [14]. After confirming that the properties of pancreas macrophages remained unchanged by the slicing procedure, we conducted imaging of intracellular free $\mathrm{Ca}^{2+}$ concentration $\left(\left[\mathrm{Ca}^{2+}\right]_{\mathrm{i}}\right)$ to determine the responses of islet-resident macrophages to stimuli activating different cell populations within the pancreas.

\section{Methods}

Mice First filial generation (F1) mice for $\mathrm{Ca}^{2+}$ imaging experiments were bred by crossing mice that contain the fluorescent calcium indicator, GCaMP3 (Rosa-GCaMP3 mice; B6, stock no. 014538; JAX laboratories, Bar Harbor, ME, USA), with mice expressing Cre recombinase in myeloid cell-specific promoters: (LyzM)-Cre (B6, stock no. 004781; JAX laboratories); $\operatorname{Tg}(C s f 1 r$-iCre) $1 \mathrm{Jwp}$ (referred to herein as Csflr-Cre; FVB, stock no. 021024; JAX laboratories); and $\mathrm{Cx} 3 \mathrm{crl} 1^{\text {cre }}$ mice (B6, stock no. 025524; JAX laboratories). Mice were housed in a temperature- and lighting-controlled room (lights on for $12 \mathrm{~h}$ ). F1 offspring expressing GCaMP3 in macrophages ( $\geq 3$ months old, both male and female) were euthanised and pancreatic tissue slices were processed as described below. All experimental protocols using mice were approved by the University of Miami Animal Care and Use Committee.

Preparation of living pancreatic tissue slices Tissue slices were prepared from 15 young adult mice $(25-30 \mathrm{~g})$ as described [14]. Mice were anaesthetised with isofluorane (2\% vol./vol.) and euthanised by cervical dislocation to prepare for pancreatic duct injection of low-gelling-temperature agarose (1.2\% [wt/vol.], dissolved in HEPES-buffered solution as described below, without BSA; catalogue no. 39346-81-1; Sigma Aldrich, St. Louis, MO, USA). Syringes $(5 \mathrm{ml})$ were filled with agarose solution, and a 30-gauge needle was used to inject in the common bile duct. After injection, tissue blocks were cut, embedded and left to solidify $\left(4^{\circ} \mathrm{C}\right)$. Living slices were then cut $(150 \mu \mathrm{m})$ on a vibroslicer (Leica VT1000s, 
Leica Biosystems, Buffalo Grove, IL, USA). Slices were incubated in HEPES-buffered solution $(125 \mathrm{mmol} / \mathrm{l} \mathrm{NaCl}$, $5.9 \mathrm{mmol} / 1 \mathrm{KCl}, 2.56 \mathrm{mmol} / 1 \mathrm{CaCl}_{2}, 1 \mathrm{mmol} / 1 \mathrm{MgCl}_{2}$, $25 \mathrm{mmol} / \mathrm{l} \mathrm{HEPES}, 0.1 \%$ BSA [wt/vol.], $\mathrm{pH}$ 7.4).

Immunohistochemistry Mice were anaesthetised, exsanguinated and perfused with $4 \%$ (wt/vol.) paraformaldehyde. Blocks of mouse pancreas $\left(0.5 \mathrm{~cm}^{3}\right)$ were post-fixed in $4 \%$ paraformaldehyde, cryoprotected ( $30 \%$ [wt/vol.] sucrose) and tissue sections $(40 \mu \mathrm{m})$ cut on a cryostat. After permeabilisation (PBS-Triton X-100 0.3\% [wt/vol.]), sections were incubated in blocking solution (Biogenex, San Ramon, CA, USA). Primary antibodies were diluted in blocking solution. To visualise macrophages, we used antibodies against ionised calcium-binding adapter molecule 1 (IBA1) (1:1000; catalogue no. 019-19741, Wako Chemicals, Richmond, VA, USA), F4/80 (1:200, catalogue no. ab6640; Abcam, Cambridge, MA, USA) and CD206 (1:100, catalogue no. 141721; Biolegend San Diego, CA, USA). We performed immunostaining for green fluorescent protein (GFP) ( $1: 200$, catalogue no. ab6658; Abcam) to visualise GFP expression under the control of the myeloid promoters (see JAX laboratories mice below). Cell nuclei were stained with DAPI. Slides were mounted with ProLong Anti Fade (Invitrogen, Waltham, MA, USA). All antibodies were validated and used as per manufacturer's instructions. See electronic supplementary materials (ESM) Methods for additional details.

$\mathrm{Ca}^{2+}$ imaging of living pancreatic tissue slices We generated mice for $\left[\mathrm{Ca}^{2+}\right]_{i}$ imaging by using $\mathrm{F} 1$ mice crossed from mice expressing Cre recombinase in myeloid cell-specific promoters with mice expressing the floxed $\mathrm{Ca}^{2+}$ indicator GCaMP3 (see above). Mice ( $\geq 3$ months old, both sexes) were euthanised, and pancreatic tissue slices were processed as described above. Living tissue slices containing GCaMP3labelled macrophages were placed in a perfusion chamber and immersed in HEPES-buffered solution. Glucose was added to the buffered solution to give a basal glucose concentration of $3 \mathrm{mmol} / \mathrm{l}$, unless otherwise specified. All stimuli were bath applied. Throughout the study we used the nonhydrolysable ATP agonist ATP $\gamma \mathrm{S}$ (adenosine 5'-(3thiotriphosphate; Tocris Biosciences, Bristol, UK). Antagonists were left to equilibrate with receptors for $5 \mathrm{~min}$ before stimulation with an agonist. For $\left[\mathrm{Ca}^{2+}\right]_{\mathrm{i}}$ imaging, a Zstack of $\sim 15-30$ confocal images was acquired every $8 \mathrm{~s}$ using a Leica SP5 confocal laser-scanning microscope. $\left[\mathrm{Ca}^{2+}\right]_{\mathrm{i}}$ responses in pancreatic macrophages were quantified as the AUC of individual traces of GCaMP3 fluorescence intensity (expressed as change in fluorescence intensity compared with baseline fluorescence $[\Delta \mathrm{F} / \mathrm{F}])$ during the application of stimuli. To be included in the analyses, $\left[\mathrm{Ca}^{2+}\right]_{\mathrm{i}}$ responses had to be reproducible in three or more pancreatic slices. We further analysed and quantified pseudopodia movement and velocity using the ImageJ plugin MTrackJ (https://imagescience.org/meijering/software/mtrackj/, accessed 14 October 2016. For immunohistochemical staining after $\left[\mathrm{Ca}^{2+}\right]_{\mathrm{i}}$ imaging, slices were processed as described in ESM Methods (Immunohistochemistry section).

Confocal imaging Confocal images (pinhole $=1$ airy unit) of randomly selected islets were acquired on a Leica SP5 confocal laser-scanning microscope with $40 \times$ magnification $(\mathrm{NA}=0.8)$. Macrophages were reconstructed in Z-stacks of 15-30 confocal images (step size $=2.5-4.0 \mu \mathrm{m}$ ) and analysed using ImageJ (version $1.51 \mathrm{~h}$; http://imagej.nih.gov/ij). Using confocal images, we established the location of macrophages within islets (endocrine) or in acinar regions (exocrine). Experiments were not blinded. To prevent bias, we used an automated method in ImageJ to segment different pancreas regions based on DAPI staining to determine macrophage positions.

Flow cytometry Islet macrophages were sorted based on the viable, $\mathrm{GFP}^{+}$and $\mathrm{F} 4 / 80^{+}$labelled cells. For non-macrophage internal controls, islet cells were also sorted based on the viable $\mathrm{GFP}^{-}, \mathrm{F} / 80^{-}$population. See ESM Methods for additional details.

RT-PCR RNA was extracted from FACS sorted islet macrophages and non-macrophage internal controls using RNeasy mini kit (Qiagen, Valencia, CA), and cDNA was prepared using the high-capacity cDNA reverse transcription kit (Applied Biosystems, Foster City, CA). cDNA products were pre-amplified 10 cycles using the TaqMan pre-amp master mix (Applied Biosystems). PCR reactions were run using TaqMan gene expression assays (Applied Biosystems) in a StepOnePlus Real-Time PCR System (Applied Biosystems).

Relative quantification of gene expression was done based on the equation relative quantification $=2^{-\Delta \mathrm{Ct}} \times 1,000,000$ where $\Delta \mathrm{Ct}$ is the difference between the threshold cycle $(\mathrm{Ct})$ value (number of cycles at which amplification for a gene reaches a threshold) of the target gene and the threshold cycle value of the ubiquitous housekeeping gene $18 \mathrm{~s}$. Genes analysed: Csf1r, $18 \mathrm{~s}$ (also known as Rn18s), Gapdh, P2rx1, P2rx2, P2rx3, P2rx4, P2rx5, P2rx6, P2rx7, P2ry1, P2ry2, P2ry4, P2ry6, P2ry10, P2ry12, P2ry13, P2ry14, Adora1, Adora2a Adora2b, Adora3.

For fold change comparisons, we used the delta delta $\mathrm{Ct}$ method, calculated by $2^{\Delta \Delta \mathrm{Ct}}$. To ensure for consistent qPCR results, $18 \mathrm{~s}$ normalised samples were compared to that of Gapdh normalised samples. Fold change differences were less than a 1.2 -fold between groups when normalised to $18 \mathrm{~s}$ vs Gapdh. Genes analysed: Csflr, 18s, Gapdh, Tnf, Illb, Tgfb1, Il6, Mmp2, Mmp9, Egf, Vegf (also known as Vegfa).

Data analyses and statistics To quantify $\left[\mathrm{Ca}^{2+}\right]_{\mathrm{i}}$ responses we calculated the AUC of the fluorescence intensity traces of GCaMP3. Our criteria for accepting $\left[\mathrm{Ca}^{2+}\right]_{\mathrm{i}}$ responses for 
analyses were that responses could be elicited two or more times by the same stimulus and that the peak signal was two or more times the baseline fluctuation. Statistical comparisons were performed using Student's $t$ test or one-way ANOVA, followed by multiple-comparison procedures with the Tukey or Dunnett's tests. Data are shown as means \pm SEM. See ESM Methods for data analysis of immunohistochemical results.

\section{Results}

Functional responses of pancreatic macrophages in situ To study the physiological responses of pancreatic macrophages we prepared living pancreatic slices for $\left[\mathrm{Ca}^{2+}\right]_{\mathrm{i}}$ imaging (Fig. 1a-c). Calcium ions $\left(\mathrm{Ca}^{2+}\right)$ act as second messengers in several intracellular signalling pathways that are activated by surface receptor classes, including $\mathrm{G}$ protein-coupled surface receptors and receptor tyrosine kinases. Increase in $\left[\mathrm{Ca}^{2+}\right]_{\mathrm{i}}$ indicates cell activation. The role of $\mathrm{Ca}^{2+}$ in immune cell function has been shown to be biologically important and well characterised in resident macrophages such as microglia and alveolar macrophages, as well as in non-myeloid lymphocyte activity $[4,5]$.

To perform $\left[\mathrm{Ca}^{2+}\right]_{\mathrm{i}}$ imaging of macrophages in real time, we generated mouse models expressing the genetically encoded $\mathrm{Ca}^{2+}$ reporter GCaMP3 (GFP-calmodulin) selectively in myeloid cells. Using a Cre-lox system, we crossed three different

a

a Mouse carrying floxed GCaMP3
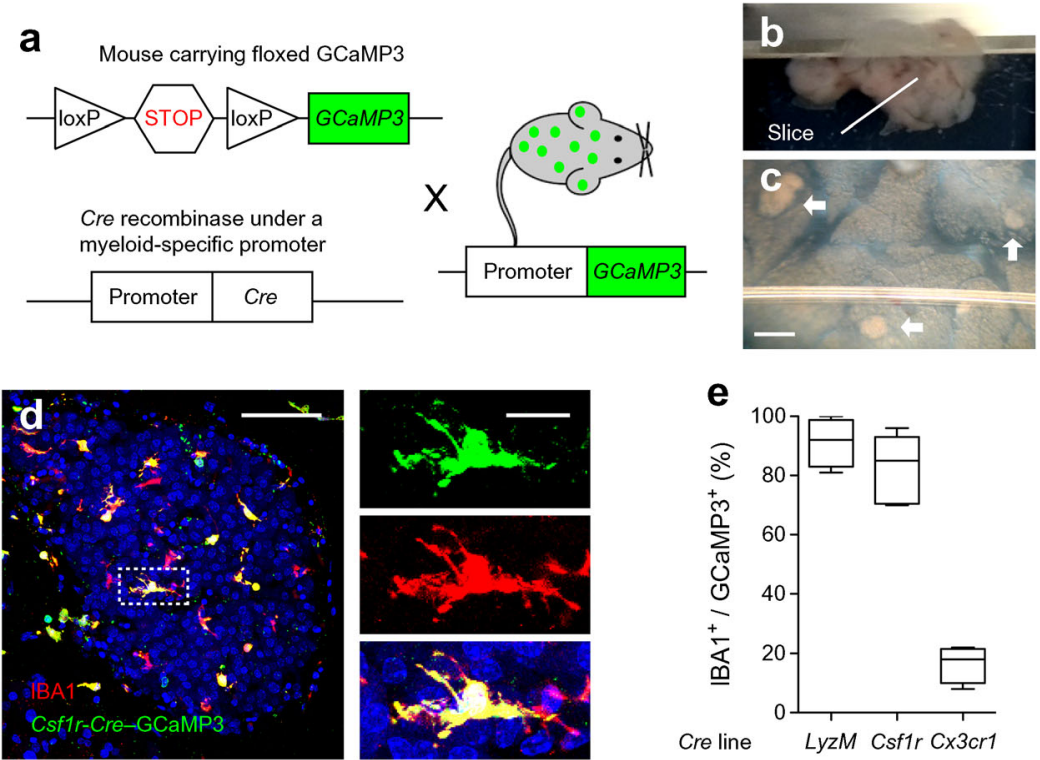
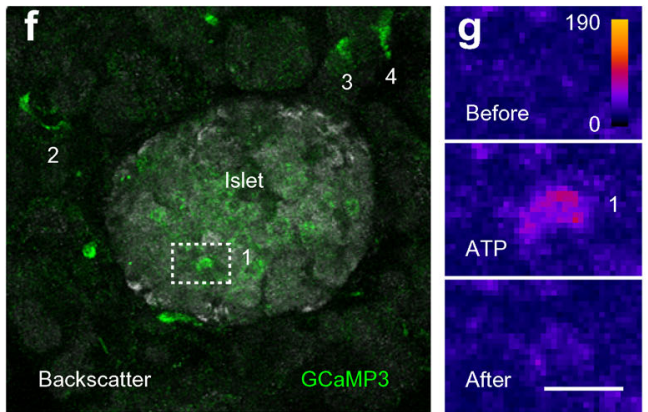

h

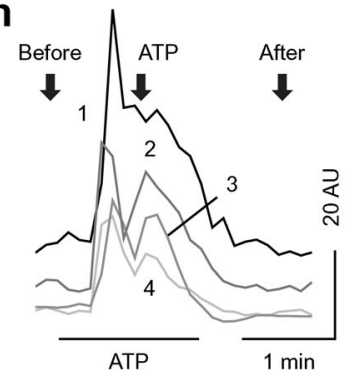

Fig. $1\left[\mathrm{Ca}^{2+}\right]_{\mathrm{i}}$ imaging of pancreas macrophages in situ. (a) Cre-lox model used to generate the $\left[\mathrm{Ca}^{2+}\right]_{\mathrm{i}}$ indicator GCaMP3 under the control of myeloid-specific promoters. (b, c) Living pancreatic tissue cut using a vibroslicer (b) and placed in a recording chamber (scale bar, $100 \mu \mathrm{m})(\mathbf{c})$. Arrows denote location of pancreatic islets. (d) Confocal image of a fixed pancreatic slice from a Csflr-Cre-GCaMP3 mouse showing GCaMP3 (green) and IBA1 (red) immunostaining, and DAPI (blue) staining of nuclei. Scale bar, $50 \mu \mathrm{m}$. Zoomed images of islet macrophages are also shown (scale bar, $10 \mu \mathrm{m})$. (e) Quantification of the proportion of IBA1positive cells within the population of $\mathrm{GCaMP}^{+}$cells in slices $(>75$ macrophages pooled from four sections in three mice per group). Box and whisker plot shows the median (horizontal line) with the lower and upper quartiles depicted by the bottom and top edge of the box, respectively. (f) Confocal image taken from a live video recording during $\left[\mathrm{Ca}^{2+}\right]_{\mathrm{i}}$ imaging of macrophages in a living slice from a GCaMP3 ${ }^{+}$ mouse. A maximal projection of a Z-stack of $\sim 40$ images is shown. The image shows islet backscatter (grey) and GCaMP3-labelled macrophages (green), with macrophages labelled 1-4. (g) Three sequential higher magnification images of macrophage 'number 1', shown in the dotted box in $(\mathbf{f})$, showing the $\left[\mathrm{Ca}^{2+}\right]_{\mathrm{i}}$ response to stimulation with ATP (100 $\mu \mathrm{mol} / \mathrm{l})$. The pseudocolour scale indicates the level of fluorescence intensity. Time points are before, during and after stimulation with ATP. Scale bar, $10 \mu \mathrm{m}$. (h) Traces of $\left[\mathrm{Ca}^{2+}\right]_{\mathrm{i}}$ responses in macrophages $1-4$ shown in (f). Arrows indicate time points before, during and after stimulation with ATP at which the images in (g) were taken. AU, arbitrary units 
strains of mice expressing Cre recombinase under myeloidspecific promoter $\left.(\mathrm{Cs} f 1 r-\mathrm{Cre}, \mathrm{Cx} 3 \mathrm{cr}]^{\mathrm{cre}},[\mathrm{Lyz} \mathrm{M}]-\mathrm{Cre}\right)$ with floxed GCaMP3 transgenic mice (Fig. 1a). In these mouse strains, Cre expression has also been reported in dendritic cells, granulocytes and monocytes. Pancreas macrophages in CsflrCre-GCaMP3 and (LyzM)-Cre-GCaMP3 mice were immunostained for the macrophage marker IBA1 and showed a high percentage $(\sim 90 \%)$ of co-localisation with GCaMP3 (Fig. 1d, e). We did not use $C x 3 c r l^{\text {cre }}$ GCaMP3 mice in our functional experiments because many non-myeloid cells expressed GCaMP3 (Fig. 1e).

Isolating macrophages from their native environment can cause changes in their phenotype and does not allow study of their dynamics and interactions with the local environment in situ [15]. In contrast, by using living pancreatic slices there is minimal disruption of tissue integrity and the islet cytoarchitecture within the acinar tissue is preserved $[14,16]$. We sought to establish that living tissue slices are suitable for the characterisation of the physiology of macrophages in their native environment. We found that macrophages in pancreatic tissue slices showed a morphology and cluster of differentiation (CD) profile comparable with those of macrophages in the pancreas of mice perfused with fixative (ESM Figs 1,2) and of islet macrophages characterised using flow cytometry analysis
(ESM Fig. 3). Based on these data, we conclude that the slicing procedure did not alter macrophage features.

After validating the transgenic mouse lines and the slicing procedure, we performed $\left[\mathrm{Ca}^{2+}\right]_{\mathrm{i}}$ imaging of macrophage responses to stimuli (e.g. ESM Video). GCaMP3-expressing macrophages could be discerned both in exocrine and endocrine regions in pancreatic slices (Fig. 1f). Islets were identified based on their strong backscatter (Fig. 1f). Macrophages in endocrine and exocrine tissues responded to ATP $\gamma \mathrm{S}$ $(100 \mu \mathrm{mol} / \mathrm{l})$ with increases in $\left[\mathrm{Ca}^{2+}\right]_{i}$ (Fig. $\left.1 \mathrm{~g}, \mathrm{~h}\right)$. After functional $\left[\mathrm{Ca}^{2+}\right]_{\mathrm{i}}$ imaging, we immunostained pancreatic slices for macrophage markers (ESM Fig. 4). With our approach, functionally characterised macrophages, easily tracked in the immunostained slices because they retained their GCaMP3 labelling, could be further classified based on their $\mathrm{CD}$ profile.

Pancreatic macrophages respond selectively to beta cellderived stimuli Pancreatic macrophages are exposed to molecules released from acinar, neural and endocrine cells (Fig. 2a). To identify interactions between these cell types and pancreas macrophages, our strategy was to apply stimuli known to activate these cells and then monitor increases in $\left[\mathrm{Ca}^{2+}\right]_{\mathrm{i}}$ in macrophages. To selectively stimulate beta cells, we raised the glucose concentration from $3 \mathrm{mmol} / \mathrm{l}$ to $16 \mathrm{mmol} / \mathrm{l}$ and found
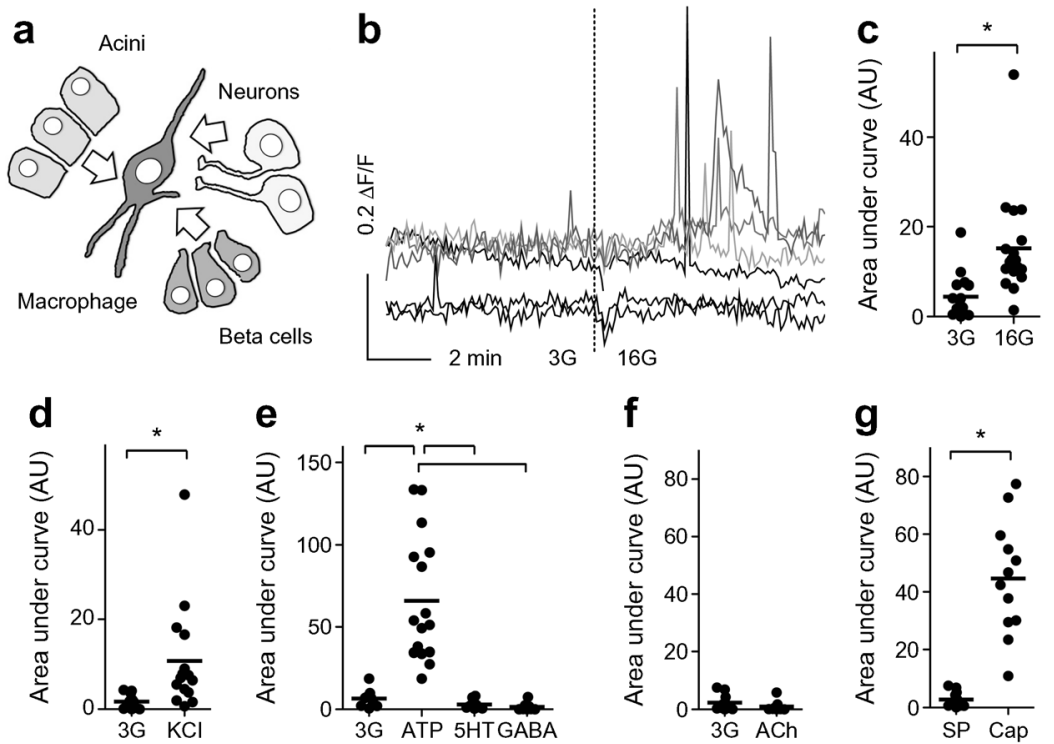

Fig. $2\left[\mathrm{Ca}^{2+}\right]_{\mathrm{i}}$ responses of pancreas macrophages to tissue-specific stimulation. (a) Diagram showing the potential inputs to pancreatic macrophages from beta cells, local autonomic neurons and pancreatic acinar cells. (b) Pancreatic macrophages in $\mathrm{Csf} 1 \mathrm{r}$-Cre-GCaMP3 mice displayed an increase in $\left[\mathrm{Ca}^{2+}\right]_{\mathrm{i}}$ when the glucose concentration was increased from $3 \mathrm{mmol} / \mathrm{l}(3 \mathrm{G})$ to $16 \mathrm{mmol} / \mathrm{l}(16 \mathrm{G})$ (grey traces). However, not all macrophages responded (black traces). Macrophages were recorded from living pancreas slices from $C s f 1 r-C r e-G C a M P 3$ mice. Dotted line represents application of $16 \mathrm{mmol} / 1$ glucose. (c) Quantification of $\left[\mathrm{Ca}^{2+}\right]_{i}$ responses as shown in (b), in living slices from Csflr-Cre-GCaMP3 mice. $n>4$ macrophages from three mice; $* p<0.05$, Student's $t$ test. (d) Quantification of macrophage $\left[\mathrm{Ca}^{2+}\right]_{\mathrm{i}}$ responses to $\mathrm{KCl}(25 \mathrm{mmol} / \mathrm{l})$. $n>8$ macrophages from three mice; ${ }^{*} p<0.05$, Student's $t$ test. (e)

Quantification of macrophage $\left[\mathrm{Ca}^{2+}\right]_{\mathrm{i}}$ responses to stimulation with ATP, serotonin (5HT) or GABA. $n=4-15$ macrophages, from more than three slices from two to four mice; $* p<0.05$, ANOVA followed by Dunnett test for multiple comparisons with the baseline (3G). (f) Quantification of $\left[\mathrm{Ca}^{2+}\right]_{\mathrm{i}}$ responses to acetylcholine (ACh, $25 \mu \mathrm{mol} / \mathrm{l}$ ). $n>6$ macrophages from two slices from two mice. (g) Quantification of $\left[\mathrm{Ca}^{2+}\right]_{\mathrm{i}}$ responses to substance P (SP, $\left.1 \mu \mathrm{mol} / \mathrm{l}\right)$ and capsaicin (Cap, $10 \mu \mathrm{mol} / \mathrm{l}) . n>9$ macrophages from three slices from three mice; $* p<0.05$, Student's $t$ test. For $(\mathbf{c}-\mathbf{g})$, the average AUC is shown for $\left[\mathrm{Ca}^{2+}\right]_{\mathrm{i}}$ responses in GCaMP3 macrophages in both endocrine and exocrine tissue. Data were also confirmed in (LyzM)-Cre-GCaMP3 mice. AU, arbitrary units 
that this increased the frequency and amplitude of $\left[\mathrm{Ca}^{2+}\right]_{\mathrm{i}}$ responses in macrophages (Fig. 2b, c). Cell membrane depolarisation with $\mathrm{KCl}(25 \mathrm{mmol} / \mathrm{l})$, which stimulates endocrine cells and neurons, produced similar $\left[\mathrm{Ca}^{2+}\right]_{\mathrm{i}}$ increases in macrophages (Fig. 2d). Macrophages in slices did not respond to application of acetylcholine $(100 \mu \mathrm{mol} / \mathrm{l})$, a neurotransmitter that stimulates pancreatic acinar cells and postganglionic autonomic neurons (Fig. 2f). Macrophages responded strongly to capsaicin $(10 \mu \mathrm{mol} / \mathrm{l}$; Fig. $2 \mathrm{~g})$, a stimulus for cells expressing transient receptor potential cation channel subfamily V member 1 (TRPV1) channels (e.g. visceral sensory neurons and macrophages). However, substance P (SP, $10 \mu \mathrm{mol} / \mathrm{l})$, a molecule released by sensory nerves in the context of local axon reflexes [17], did not increase $\left[\mathrm{Ca}^{2+}\right]_{\mathrm{i}}$ in macrophages.

Our results suggest that pancreas macrophages responded mainly to activation of endocrine cells. We therefore examined the effects of the signalling molecules ATP, $\gamma$ aminobutyric acid (GABA) and serotonin, which are known to be released by beta cells $[18,19]$. These potential paracrine signals also activate macrophages in other organs [20-22]. We observed that exposure to GABA or serotonin did not produce increases in macrophage $\left[\mathrm{Ca}^{2+}\right]_{\mathrm{i}}$. By contrast, ATP $\gamma \mathrm{S}$ $(50 \mu \mathrm{mol} / 1)$ elicited the strongest increases in $\left[\mathrm{Ca}^{2+}\right]_{\mathrm{i}}$ (Fig. 2e).

Identification of functional purinergic receptors in pancreas macrophages We identified ATP as a strong activator of islet and acinar macrophages (Fig. 2e). The P2 receptor antagonist suramin $(20 \mu \mathrm{mol} / \mathrm{l})$ blocked $\left[\mathrm{Ca}^{2+}\right]_{\mathrm{i}}$ responses of pancreatic macrophages to ATP (Fig. 3a), confirming that purinergic receptors are involved. Macrophages in the exocrine tissue showed greater $\left[\mathrm{Ca}^{2+}\right]_{\mathrm{i}}$ responses to low levels of ATP $(10 \mu \mathrm{mol} / \mathrm{l})$, while higher levels of ATP $(1 \mathrm{mmol} / \mathrm{l})$ elicited $\left[\mathrm{Ca}^{2+}\right]_{\mathrm{i}}$ responses in endocrine and exocrine macrophages equally (Fig. 3b, c). BzATP $(10 \mu \mathrm{mol} / \mathrm{l})$, a $\mathrm{P} 2 \mathrm{X}_{7}$ receptor agonist, $\mathrm{ADP}(10 \mu \mathrm{mol} / \mathrm{l})$, a $\mathrm{P} 2 \mathrm{Y}$ receptor agonist, MRS2693 $(1 \mu \mathrm{mol} / \mathrm{l})$, a nucleotide with preference for $\mathrm{P}_{2} \mathrm{Y}_{6}$ receptors, and MRS2768 ( $1 \mu \mathrm{mol} / \mathrm{l})$, an agonist with preference for $\mathrm{P}_{2} \mathrm{Y}_{2}$ receptors, also stimulated $\left[\mathrm{Ca}^{2+}\right]_{\mathrm{i}}$ responses in

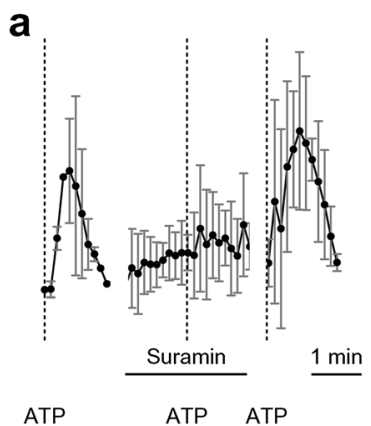

b
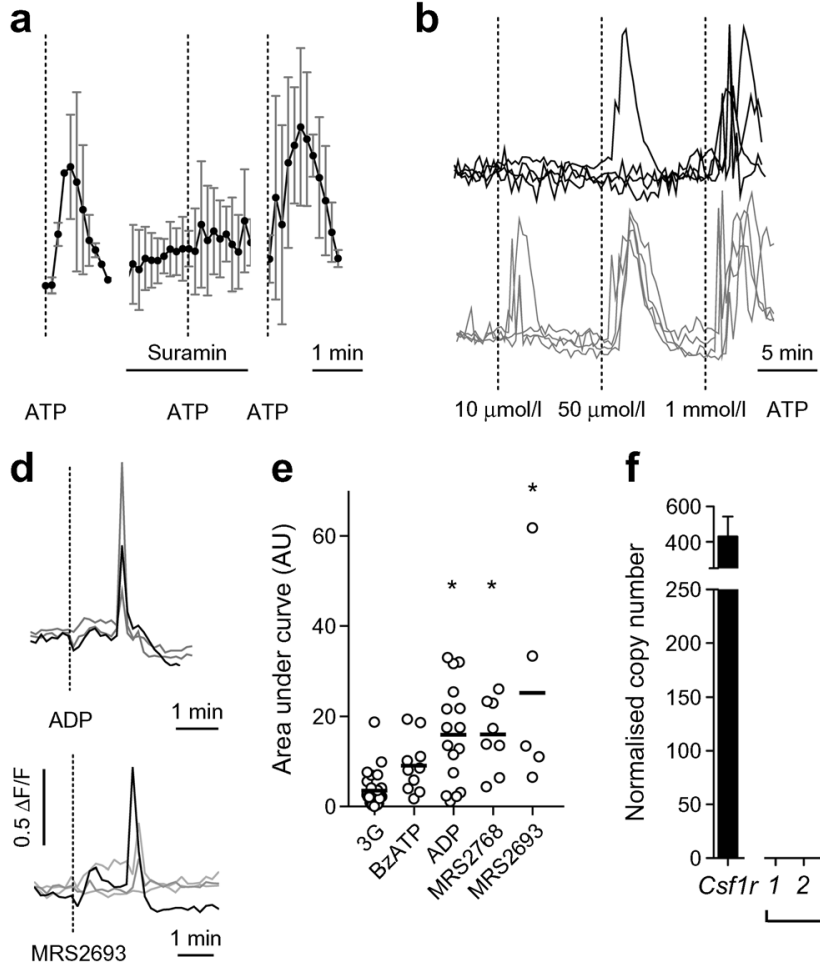

Fig. 3 Islet-resident macrophages express functional purinergic receptors. (a) Traces of $\left[\mathrm{Ca}^{2+}\right]_{\mathrm{i}}$ responses to ATP $(100 \mu \mathrm{mol} / 1)$ from CsfirCre-GCaMP3 islet macrophages in pancreatic slices showing that responses were inhibited by suramin $(20 \mu \mathrm{mol} / \mathrm{l})$, a broad P2 receptor antagonist. (b) $\left[\mathrm{Ca}^{2+}\right]_{\mathrm{i}}$ responses of individual macrophages to increasing concentrations of ATP in the islet (black) and exocrine regions (grey) of pancreatic slices from $\mathrm{Cs} f \mathrm{r}$-Cre-GCaMP3 mice. Vertical dotted lines denote start of 2 min stimulation. (c) Concentration-response curves for $\left[\mathrm{Ca}^{2+}\right]_{\mathrm{i}}$ after stimulation of macrophages with ATP in islet (black circles) and exocrine regions (grey circles). Responses were quantified as AUC and were normalised as a percentage of the maximum response. $n=9$ cells pooled from nine slices from four mice. (d) Traces of $\left[\mathrm{Ca}^{2+}\right]_{\mathrm{i}}$ responses to ADP $(10 \mu \mathrm{mol} / \mathrm{l})$ and MRS2693 $(1 \mu \mathrm{mol} / \mathrm{l})$ in pancreatic slices
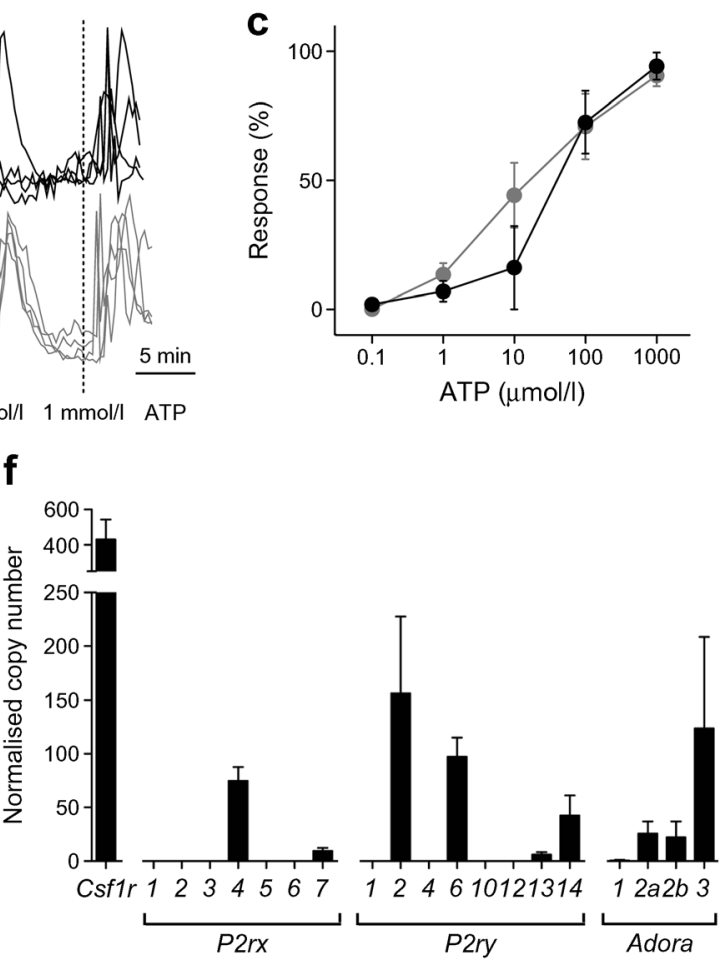

from Csf1r-Cre-GCaMP3 mice. (e) Quantification of $\left[\mathrm{Ca}^{2+}\right]_{\mathrm{i}}$ responses to $3 \mathrm{mmol} / \mathrm{l}$ glucose $(3 \mathrm{G})$, BzATP $\left(10 \mu \mathrm{mol} / \mathrm{l}\right.$; a $\mathrm{P} 2 \mathrm{X}_{7}$ receptor agonist) and the P2Y receptor agonists: ADP $(10 \mu \mathrm{mol} / \mathrm{l}), \mathrm{MRS} 2768(1 \mu \mathrm{mol} / \mathrm{l})$ and MRS2693 $(1 \mu \mathrm{mol} / \mathrm{l})$. Data are presented as mean \pm SEM. The dot plot shows the average AUC (black bar) for $\left[\mathrm{Ca}^{2+}\right]_{i}$ responses to the stimuli. $n>5$ macrophages from two slices from two or three mice; $* p<0.05$, ANOVA followed by Dunnett test for multiple comparisons to the baseline (3G). (f) Quantification of the mRNA levels of purinergic receptors ( $P 2 r x, P 2 r y$ and Adora) expressed by sorted islet macrophages from $n=3$ independent isolations from more than three mice. Data were also confirmed in (LyzM)-Cre-GCaMP3 mice. AU, arbitrary units. Data are presented as mean \pm SEM 
macrophages (Fig. 3d, e). The P2Y receptor agonists elicited significant increases in the $\left[\mathrm{Ca}^{2+}\right]_{i}$ responses in macrophages (Fig. 3e).

To confirm the presence of specific purinergic receptors expressed by islet macrophages, previously identified using a physiological approach above, we performed RT-PCR on FACS-sorted macrophages from isolated islets. We found expression of mRNA for the macrophage-specific gene Csflr, P2X receptors $(P 2 r x 4, P 2 r x 7), \mathrm{P} 2 \mathrm{Y}$ receptors $(P 2 r y 2, P 2 r y 6$, $p 2 r y 14)$ and the $\mathrm{P} 1$ receptors (Adora1, Adora2a, Adora2b and Adora3; Fig. 3f). Because other cells within the islet are known to respond to ATP, we compared purinergic receptor gene expression of islet macrophages with that the $\mathrm{F} 4 / 80^{-}$islet cell population (ESM Fig. 5). We found that most receptor genes were more highly expressed in macrophages: in particular, P2rx4 (ninefold), P2rx7 (82-fold), P2ry2 (52-fold), P2ry4 (15-fold), P2ry6 (670-fold) and the P1 receptor Adora2a (13-fold). Only the expression of Adoral, the gene for a $\mathrm{P} 1$ receptor known to be highly expressed in alpha cells [23], was 10.5 -fold higher in the islet $\left(\mathrm{F} 4 / 80^{-}\right)$population. The results suggest that islet macrophages express high levels of purinergic receptor genes.

Acutely culturing islets with ATP alters macrophage gene expression Pancreatic macrophages have been shown to modulate gene expression of cytokines and chemokines during
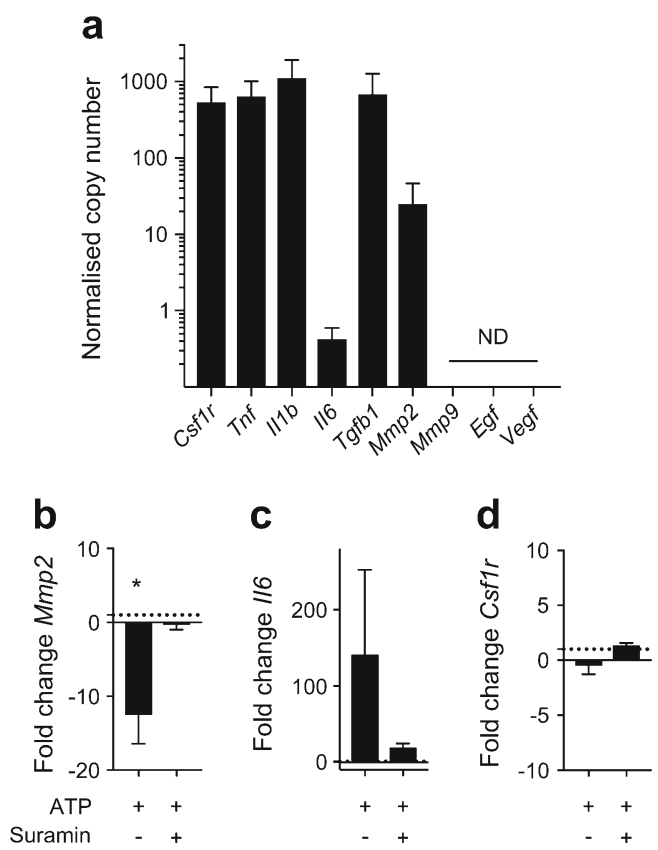

Fig. 4 Culturing islets with ATP (16 h) alters macrophage gene expression from the basal state. (a) mRNA expression from FACS-sorted islet macrophages from $\mathrm{Csf} 1 \mathrm{r}-\mathrm{Cr}-\mathrm{GCaMP} 3$ mice. ND, not detected. (b-d) Changes in Mmp2, Il6 and Csflr gene expression compared with that in control islet culture medium with and without suramin $(20 \mu \mathrm{mol} / \mathrm{l})$, presented as fold change. Data are presented as mean \pm SEM; $n=3$ independent islet preparations, with islets pooled from five mice per preparation; * $p<0.05$, one-sample $t$ test to a hypothetical value of 1 diet alteration [9]. We identified functional purinergic receptors in islet macrophages and sought to identify the direct effect of acute purinergic stimulation on islet macrophage gene expression. In FACS-sorted islet macrophages, we found mRNA expression of genes encoding for matrix metalloproteinase (Mmp2) and genes characteristic of both M1 (Tnfa [also known as Tnf], Illb) and M2 (Tgfb [Tgfbl], Ilo) macrophage polarisation (Fig. 4a). Upon acute stimulation with ATP $(50 \mu \mathrm{mol} / \mathrm{l}, 16 \mathrm{~h})$ we found $\mathrm{Mmp} 2$ to be significantly downregulated when compared with the control islet culture medium $(5.5 \mathrm{mmol} / \mathrm{l}$ glucose RPMI + supplements $)$ treatment; the purinergic receptor inhibitor suramin $(20 \mu \mathrm{mol} / \mathrm{l})$ blocked the effect of ATP (Fig. 4b). Il6 expression was increased compared with control condition, although the change was not significant. There was no observable change in the macrophage-specific gene Csflr (Fig. 4c) or other genes identified in the basal state (Fig. 4a). These effects were mirrored in islets acutely cultured with high glucose concentration
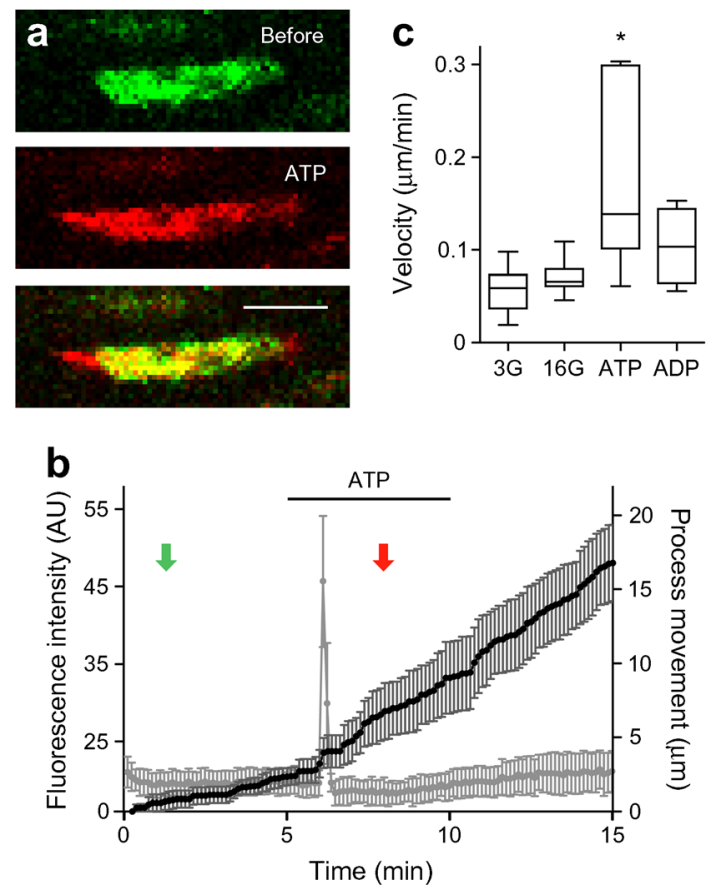

Fig. 5 ATP stimulates movement of macrophage pseudopodia. (a) Sequential images of a Csflr-Cre-GCaMP3-derived macrophage taken during incubation with $3 \mathrm{mmol} / \mathrm{l}$ glucose (green) and after stimulation with ATP $(50 \mu \mathrm{mol} / 1$, red). Merged image shows extended macrophage pseudopodia (red). Co-localisation of green (before ATP stimulation) and red (after ATP stimulation) staining is shown in yellow. Scale bar, $10 \mu \mathrm{m}$. Images were acquired at the time points denoted by the green and red arrows in (b). (b) Pancreatic macrophage $\mathrm{Ca}^{2+}$ responses to ATP (50 $\mathrm{\mu mol} / \mathrm{l}$; grey line) with pseudopodia process movement (black line). (c) Quantification of the velocity of macrophage processes during stimulation with $3 \mathrm{mmol} / \mathrm{l}$ glucose (3G), $16 \mathrm{mmol} / \mathrm{l}$ glucose (16G), ATP $(50 \mu \mathrm{mol} / \mathrm{l})$ and ADP $(10 \mu \mathrm{mol} / \mathrm{l})$. Macrophage pseudopodia showed increased velocity during ATP stimulation. Box and whisker plot shows the median (horizontal line) with the lower and upper quartiles depicted by the bottom and top edge of the box, respectively. $n>7$ macrophages from three mice; $* p<0.05$ Student's $t$ test. AU, arbitrary units 
(16 mmol/1; ESM Fig. 6), although the results were not significant.

ATP induces pseudopodia movement of pancreatic macrophages In many tissues, macrophages display characteristic movements of their fine processes to scan the microenvironment [24]. Because pancreas macrophages responded strongly

a

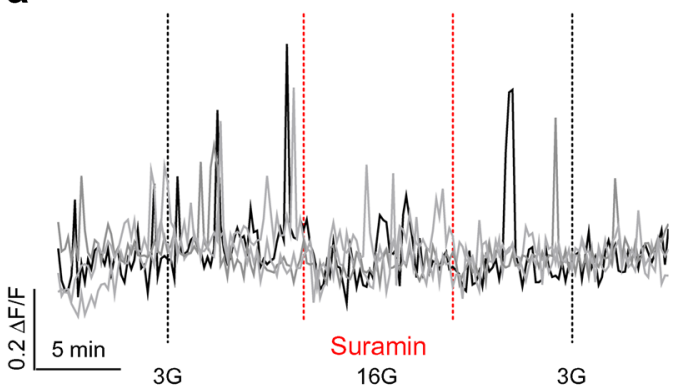

d

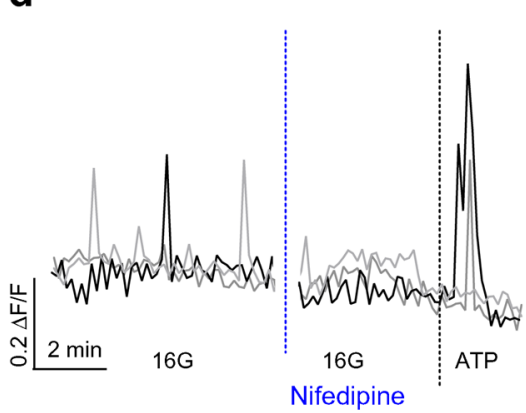

e

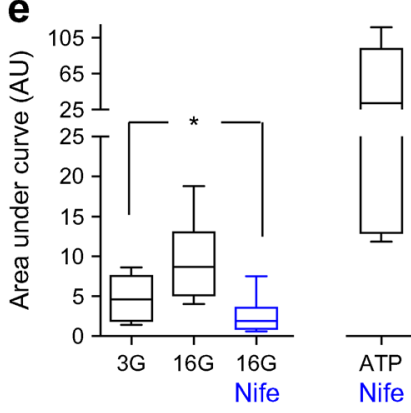

to ATP, we reasoned that these increases in $\left[\mathrm{Ca}^{2+}\right]_{\mathrm{i}}$ could lead to changes in dynamic behaviour. Therefore, in parallel with measurement of $\left[\mathrm{Ca}^{2+}\right]_{\mathrm{i}}$, we recorded movement of macrophage pseudopodia (Fig. 5a). Modest increases in pseudopodia movement were observed after exposure to ADP $(10 \mu \mathrm{mol} / \mathrm{l})$, but no observable changes in movement were seen during high glucose stimulation. Stimulation with ATP b

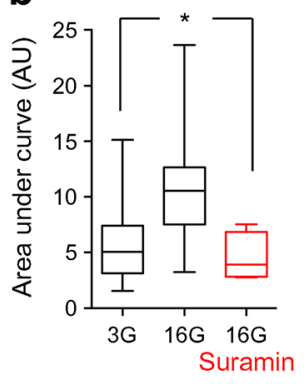

C

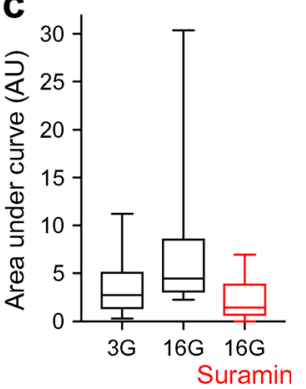

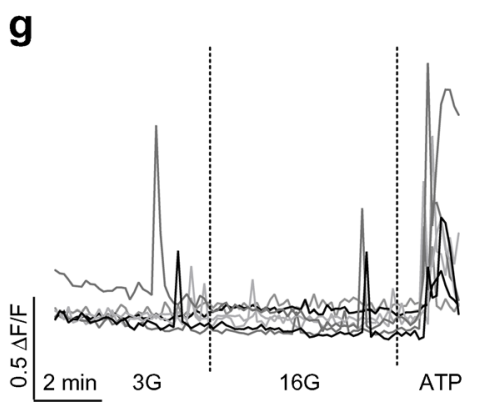

h

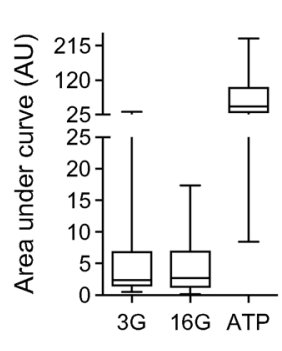

i

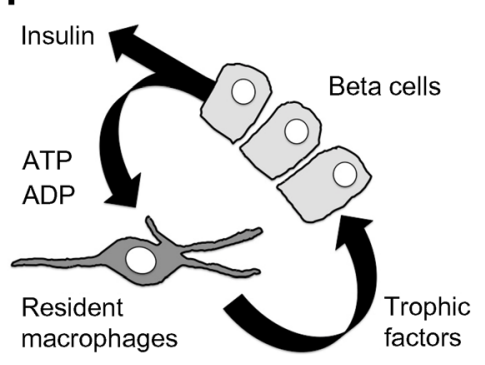

Fig. 6 Pancreatic macrophages sense endogenous ATP released from insulin-secreting beta cells. (a) Spontaneous activity $\left(\left[\mathrm{Ca}^{2+}\right]_{\mathrm{i}}\right.$ responses) of pancreatic macrophages increased when beta cells were stimulated by increasing the glucose concentration from $3 \mathrm{mmol} / \mathrm{l}(3 \mathrm{G})$ to $16 \mathrm{mmol} / \mathrm{l}$ $(16 \mathrm{G})$ in $\mathrm{Cs} f 1 \mathrm{r}$-Cre-GCaMP3 mice. Grey and black traces are response traces from individual cells. Spontaneous activity was inhibited by suramin $(20 \mu \mathrm{mol} / \mathrm{l})$. Vertical, dotted lines denote exchange of solutions. Red dotted lines denote the start and stop of suramin $(20 \mu \mathrm{mol} / \mathrm{l})$ application. (b, c) Quantification of $\left[\mathrm{Ca}^{2+}\right]_{\mathrm{i}}$ response (AUC of traces shown in a), during exposure to $3 \mathrm{G}, 16 \mathrm{G}$ or $16 \mathrm{G}$ with suramin $(20 \mu \mathrm{mol} / \mathrm{l})$, in macrophages from pancreatic islets $(\mathbf{b})$ and from exocrine macrophages (c). $n=4-20$ cells pooled from three pancreatic slices from three mice; $* p<0.05$, ANOVA followed by Tukey test for multiple comparisons. (d) Activity in pancreatic macrophages induced by increasing the glucose concentration from $3 \mathrm{G}$ to $16 \mathrm{G}$ was inhibited by nifedipine $(10 \mu \mathrm{mol} / \mathrm{l})$. (e) Quantification of $\left[\mathrm{Ca}^{2+}\right]_{\mathrm{i}}$ responses (AUC of traces shown in d) during exposure to $3 \mathrm{G}, 16 \mathrm{G}, 16 \mathrm{G}$ with nifedipine (Nife, $10 \mu \mathrm{mol} / \mathrm{l})$ and $16 \mathrm{G}$ with ATP $(50 \mu \mathrm{mol} / \mathrm{l})$ and nifedipine $(10 \mu \mathrm{mol} / \mathrm{l}) . n=6-12$ cells pooled from three pancreatic slices from three $\mathrm{Csflr}$-Cre-GCaMP3 mice; $* p<0.05$, ANOVA followed by Tukey test for multiple comparisons. (f) Quantification of $\left[\mathrm{Ca}^{2+}\right]_{\mathrm{i}}$ responses (AUC) to exchanging solutions between $3 \mathrm{G}, \mathrm{KCl}(25 \mathrm{mmol} / \mathrm{l})$ and $\mathrm{KCl}(25 \mathrm{mmol} / \mathrm{l})$ with suramin $(20 \mu \mathrm{mol} / \mathrm{l}) . n=9$ cells pooled from three pancreatic slices from two mice; $* p<0.05$, ANOVA followed by Tukey test for multiple comparisons. (g) Spontaneous activity in pancreatic macrophages did not increase when the glucose concentration was raised from $3 \mathrm{G}$ to $16 \mathrm{G}$ in pancreatic slices devoid of islets. Macrophages became activated during stimulation with ATP $(50 \mu \mathrm{mol} / 1)$. (h) Quantification of $\left[\mathrm{Ca}^{2+}\right]_{\mathrm{i}}$ increases (AUC of traces shown in g). $n=14$ cells pooled from three pancreatic slices from three mice. (i) Proposed model of macrophage communication with beta cells. Box and whisker plots show the median (horizontal line) with the lower and upper quartiles depicted by the bottom and top edge of the box, respectively. AU, arbitrary units 
$(50 \mu \mathrm{mol} / 1)$ elicited a sharp $\left[\mathrm{Ca}^{2+}\right]_{\mathrm{i}}$ response and simultaneously increased the velocity of pseudopodia movement of macrophages (Fig. 5b, c). Thus, pancreas macrophages respond to ATP by increasing the extent and rate of microenvironment scanning. Macrophage motility, however, may not be increased by the lower levels of ATP present during physiological stimulation of beta cells.

Pancreatic macrophages respond to endogenous ATP released from beta cells ATP levels are generally higher inside the cell, and increased extracellular ATP generally reflects cell disruption. However, ATP can be released physiologically into the extracellular space through various mechanisms including exocytosis. In the islet microenvironment, macrophages are exposed to ATP as it is coreleased with insulin from beta cells [18]. Within the mouse pancreas, islets are uniquely competent to release ATP because they express vesicular nucleotide transporter (VNUT) [25]. Concentrations of ATP can rise above $25 \mu \mathrm{mol} / 1$ around stimulated beta cells [26], matching the $\mathrm{EC}_{50}$ of the observed macrophage response to ATP (15$30 \mu \mathrm{mol} / \mathrm{l}$, Fig. $3 \mathrm{c}$ ). We therefore hypothesised that macrophages sense local changes in ATP concentration during activation of beta cells.

To test this hypothesis, we increased the glucose concentration from $3 \mathrm{mmol} / \mathrm{l}$ to $16 \mathrm{mmol} / \mathrm{l}$ and challenged the $\left[\mathrm{Ca}^{2+}\right]_{\mathrm{i}}$ responses in macrophages with suramin $(20 \mu \mathrm{mol} /$ 1). After suramin washout, activity in macrophages increased again and later subsided after return to low glucose concentrations (Fig. 6a). Suramin inhibited the increased activity during exposure to $16 \mathrm{mmol} / \mathrm{l}$ glucose quantitatively (Fig. 6b), indicating that purinergic receptors mediate the macrophage responses to beta cell activation with increased glucose concentration. By contrast, exocrine macrophages showed modest, non-significant, increases in activity during stimulation with $16 \mathrm{mmol} / \mathrm{l}$ glucose (Fig. 6c). To uncouple the direct effect of glucose on pancreatic macrophages and to pinpoint the beta cell as the source of increased spontaneous activity, we used the L-type voltage-gated $\mathrm{Ca}^{2+}$ channel blocker nifedipine, a known inhibitor of beta cell secretion [27]. Application of nifedipine $(10 \mu \mathrm{mol} / \mathrm{l})$ blocked $\left[\mathrm{Ca}^{2+}\right]_{\mathrm{i}}$ responses elicited by $16 \mathrm{mmol} /$ 1 glucose (Fig. 6d), without affecting ATP sensitivity in islet macrophages (Fig. 6e). $\mathrm{KCl}$ depolarisation induced increases in macrophage $\left[\mathrm{Ca}^{2+}\right]_{\mathrm{i}}$, but not in the presence of suramin (Fig. 6f). These results indicate that ATP released endogenously from beta cells stimulates pancreas macrophages. There was no change in macrophage $\left[\mathrm{Ca}^{2+}\right]_{\mathrm{i}}$ response during stimulation with $16 \mathrm{mmol} / 1 \mathrm{glu}-$ cose in pancreatic slices devoid of islets (Fig. 6g, h). From these data, we propose a model for communication between pancreatic islets and their resident macrophages in which islet-resident macrophages respond to ATP and other purines released from beta cells under physiological stimulation (Fig. 6i).

\section{Discussion}

Our results demonstrate that pancreatic islet macrophages express a complement of purinergic receptors that detect endogenous levels of interstitial ATP. While extracellular ATP generally reflects cell disruption, we established here that macrophages respond to ATP secreted from beta cells. ATP can therefore be considered a bona fide paracrine signal that the beta cell uses to communicate with resident macrophages.

Functional imaging in living slices allowed us to study local interactions between islet endocrine cells, local neurons, acinar cells and resident macrophages. While $\mathrm{Ca}^{2+}$ imaging of macrophages is commonly performed in other tissues $[5,28,29]$, it had not been attempted in the pancreas. Immune cell infiltration and movement has been monitored in the native pancreas [30-32] but given the low spatial resolution and limited access to local drug application it is unlikely that these in vivo approaches would allow the physiological characterisation and pharmacological interrogation of macrophages in situ we conducted here.

Using our approach, we determined that islet macrophages respond to activation of endocrine cells but not to stimulation of acinar cells. Macrophage responses to endocrine cell activation with high glucose concentrations were mediated by ATP receptors. Is very likely that most of the ATP released under these conditions is derived from beta cells because: (1) beta cells of the mouse islet are the predominant cell type responding to high glucose; (2) in pancreas slices that did not contain islets, acinar macrophages did not respond to high glucose concentration; (3) beta cells release ATP from insulin granules $[18,33,34]$ and (4) beta cells are the only pancreatic cells that express VNUT [25], making them uniquely competent to release stored ATP. Because ATP release is tightly coupled to insulin secretion, extracellular ATP levels can be considered a proxy for beta cell secretory activity. ATP signalling thus converts islet macrophages into local sensors of the beta cell's hormonal output.

ATP may trigger important physiological processes in islet macrophages. Indeed, purinergic signalling has been shown to be essential for macrophage functions such as chemotaxis [35], phagocytosis [36] and cytokine production [37]. We determined that ATP induces increases in $\left[\mathrm{Ca}^{2+}\right]_{\mathrm{i}}$ and movement of macrophage pseudopodia but the exact secretory responses triggered in islet macrophages when exposed to ATP remain unclear. Recent 
studies suggest that macrophages play a trophic role in beta cell proliferation but the results were obtained under extreme conditions which involved recruited macrophages $[7,8,12]$.

In addition to proliferation factors, local release of proinflammatory cytokines, such as IL- $1 \beta$ has been shown to modulate insulin secretion [38] and is sufficient to damage human pancreatic islets [39]. IL-1 $\beta$ release from islet macrophages may act in a feedback loop to regulate insulin secretion. In our limited study, we did not detect significant differences in cytokine gene expression during acute treatment with ATP or high glucose. However, we did detect a significant downregulation of Mmp2. It is important to determine whether the purinergic axis between beta cells and resident macrophages regulates local inflammation (e.g. IL-1 $\beta$ [38]) and tissue integrity (e.g. matrix metalloproteinase $2[40]$ ) as well as trophic support (e.g. TGF- $\beta$ [41], Il-6 [42]) during physiological and pathological states.

To fulfil their homeostatic role, macrophages must monitor the local microenvironment to detect changes in tissue characteristics, such as cell number and composition, and the acidity and osmolarity of interstitial fluids [43]. Our results suggest that resident macrophages use ATP receptors and probably TRPV1 receptors to respectively monitor beta cell activity and the acidity of the interstitial milieu in the islet. Islet macrophages have been shown to be key players in autoimmune destruction of the islet caused by type 1 diabetes [44-51] and have a role in producing inflammation during type 2 diabetes [52, 53]. Here, we show that islet macrophages monitor and respond to local environmental cues not only during extreme challenges such as inflammation and autoimmunity but also during less dramatic alterations in tissue physiology. Sensing the microenvironment helps the macrophage gauge its production of factors that promote islet tissue stability.

Acknowledgements The authors are grateful to O. Umland, the manager of the flow cytometry facility of the Diabetes Research Institute at the University of Miami, for providing expert help with flow cytometry analysis.

Data availability All data generated or analysed during this study are included in this published article (and its supplementary files).

Funding This work was supported by the Diabetes Research Institute Foundation and National Institutes of Health grants R56-DK-084321, R01-DK-084321, R21-ES-025673 and R01-DK111538 to AC. JS and SS were supported by the German Research Foundation (DFG)-SFB/ Transregio 127 and German Ministry for Education and Research (BMBF) to the German Centre for Diabetes Research (DZD).
Duality of interest The authors declare that there is no duality of interest associated with this manuscript.

Contribution statement JRW contributed to the study's design, collection of data and analysis and interpretation of results. JRW wrote the original draft of the manuscript. MM and JA contributed to the collection and analysis of data and critically edited the final version of the manuscript for intellectual content. JS contributed to the implementation of the pancreatic slice technique and critically edited the final version of the manuscript for intellectual content. SS contributed to the conception of the study and provided expert advice for performing the pancreatic slice and critically edited the final version of the manuscript for intellectual content. MB and KA contributed to the RT-PCR data analysis for expression of purinergic receptors and critically edited the final version of the manuscript for intellectual content. RR-D contributed to the conception of the study, collection of data and maintenance of animal colonies and critically edited the final version of the manuscript for intellectual content. AC contributed to the conception of the design of the study and data interpretation and reviewed and edited the original draft of the manuscript. AC is the guarantor of this work and has full access to the data and takes responsibility for the integrity of the work. All authors approved the final version of the manuscript.

\section{References}

1. Jacques-Silva MC, Correa-Medina M, Cabrera O et al (2010) ATPgated $\mathrm{P} 2 \mathrm{X} 3$ receptors constitute a positive autocrine signal for insulin release in the human pancreatic beta cell. Proc Natl Acad Sci U S A 107:6465-6470

2. Almaca J, Molina J, Menegaz D et al (2016) Human beta cells produce and release serotonin to inhibit glucagon secretion from alpha cells. Cell Rep 17:3281-3291

3. Okabe Y, Medzhitov R (2016) Tissue biology perspective on macrophages. Nat Immunol 17:9-17

4. Szalay G, Martinecz B, Lenart N et al (2016) Microglia protect against brain injury and their selective elimination dysregulates neuronal network activity after stroke. Nat Commun 7:11499

5. Westphalen K, Gusarova GA, Islam MN et al (2014) Sessile alveolar macrophages communicate with alveolar epithelium to modulate immunity. Nature 506:503-506

6. Banaei-Bouchareb L, Gouon-Evans V, Samara-Boustani D et al (2004) Insulin cell mass is altered in Csflop/Csflop macrophagedeficient mice. J Leukoc Biol 76:359-367

7. Brissova M, Aamodt $\mathrm{K}$, Brahmachary $\mathrm{P}$ et al (2014) Islet microenvironment, modulated by vascular endothelial growth factor-A signaling, promotes beta cell regeneration. Cell Metab 19:498-511

8. Riley KG, Pasek RC, Maulis MF et al (2015) Macrophages are essential for CTGF-mediated adult beta-cell proliferation after injury. Mol Metab 4:584-591

9. Calderon B, Carrero JA, Ferris ST et al (2015) The pancreas anatomy conditions the origin and properties of resident macrophages. $\mathrm{J}$ Exp Med 212:1497-1512

10. Yin N, Xu J, Ginhoux F et al (2012) Functional specialization of islet dendritic cell subsets. J Immunol 188:4921-4930

11. Allavena P, Sica A, Solinas G, Porta C, Mantovani A (2008) The inflammatory micro-environment in tumor progression: the role of tumor-associated macrophages. Crit Rev Oncol Hematol 66:1-9

12. Criscimanna A, Coudriet GM, Gittes GK, Piganelli JD, Esni F (2014) Activated macrophages create lineage-specific microenvironments for pancreatic acinar- and $\beta$-cell regeneration in mice. Gastroenterology 147:1106-1118 e11 
13. Stence N, Waite M, Dailey ME (2001) Dynamics of microglial activation: a confocal time-lapse analysis in hippocampal slices. Glia 33:256-266

14. Marciniak A, Cohrs CM, Tsata V et al (2014) Using pancreas tissue slices for in situ studies of islet of Langerhans and acinar cell biology. Nat Protoc 9:2809-2822

15. Chamberlain LM, Holt-Casper D, Gonzalez-Juarrero M, Grainger DW (2015) Extended culture of macrophages from different sources and maturation results in a common M2 phenotype. J Biomed Mater Res A 103:2864-2874

16. Huang YC, Rupnik M, Gaisano HY (2011) Unperturbed islet $\alpha$-cell function examined in mouse pancreas tissue slices. J Physiol 589: 395-408

17. Lau HY, Wong FL, Bhatia M (2005) A key role of neurokinin 1 receptors in acute pancreatitis and associated lung injury. Biochem Biophys Res Commun 327:509-515

18. Detimary P, Jonas JC, Henquin JC (1996) Stable and diffusible pools of nucleotides in pancreatic islet cells. Endocrinology 137: 4671-4676

19. Ekholm R, Ericson LE, Lundquist I (1971) Monoamines in the pancreatic islets of the mouse. Subcellular localization of 5hydroxytryptamine by electron microscopic autoradiography. Diabetologia 7:339-348

20. Inoue K, Tsuda M (2012) Purinergic systems, neuropathic pain and the role of microglia. Exp Neurol 234:293-301

21. Konno M, Shirakawa H, Iida S et al (2012) Stimulation of transient receptor potential vanilloid 4 channel suppresses abnormal activation of microglia induced by lipopolysaccharide. Glia 60:761-770

22. Schwiebert EM, Zsembery A (2003) Extracellular ATP as a signaling molecule for epithelial cells. Biochim Biophys Acta 1615:7-32

23. Hillaire-Buys D, Bertrand G, Gross R, Loubatieres-Mariani MM (1987) Evidence for an inhibitory A1 subtype adenosine receptor on pancreatic insulin-secreting cells. Eur J Pharmacol 136:109-112

24. Nimmerjahn A, Kirchhoff F, Helmchen F (2005) Resting microglial cells are highly dynamic surveillants of brain parenchyma in vivo. Science 308:1314-1318

25. Geisler JC, Corbin KL, Li Q, Feranchak AP, Nunemaker CS, Li C (2013) Vesicular nucleotide transporter-mediated ATP release regulates insulin secretion. Endocrinology 154:675-684

26. Hazama A, Hayashi S, Okada Y (1998) Cell surface measurements of ATP release from single pancreatic beta cells using a novel biosensor technique. Pflugers Arch 437:31-35

27. Yang SN, Berggren PO (2006) The role of voltage-gated calcium channels in pancreatic $\beta$-cell physiology and pathophysiology. Endocr Rev 27:621-676

28. Davalos D, Grutzendler J, Yang G et al (2005) ATP mediates rapid microglial response to local brain injury in vivo. Nat Neurosci 8: $752-758$

29. Moghimi SM, Patel HM (1990) Calcium as a possible modulator of Kupffer cell phagocytic function by regulating liver-specific opsonic activity. Biochim Biophys Acta 1028:304-308

30. Lee CJ, Spalding AC, Ben-Josef E, Wang L, Simeone DM (2010) In vivo bioluminescent imaging of irradiated orthotopic pancreatic cancer xenografts in nonobese diabetic-severe combined immunodeficient mice: a novel method for targeting and assaying efficacy of ionizing radiation. Transl Oncol 3:153-159

31. Martinic MM, von Herrath MG (2008) Real-time imaging of the pancreas during development of diabetes. Immunol Rev 221:200 213

32. Turvey SE, Swart E, Denis MC et al (2005) Noninvasive imaging of pancreatic inflammation and its reversal in type 1 diabetes. J Clin Invest 115:2454-2461

33. Braun M, Wendt A, Karanauskaite J et al (2007) Corelease and differential exit via the fusion pore of GABA, serotonin, and ATP from LDCV in rat pancreatic beta cells. J General Physiol 129:221231

34. MacDonald PE, Braun M, Galvanovskis J, Rorsman P (2006) Release of small transmitters through kiss-and-run fusion pores in rat pancreatic beta cells. Cell Metab 4:283-290

35. Kronlage M, Song J, Sorokin L et al (2010) Autocrine purinergic receptor signaling is essential for macrophage chemotaxis. Sci Signal 3:ra55

36. Koizumi S, Shigemoto-Mogami Y, Nasu-Tada K et al (2007) UDP acting at P2Y6 receptors is a mediator of microglial phagocytosis. Nature 446:1091-1095

37. Perregaux DG, McNiff P, Laliberte R, Conklyn M, Gabel CA (2000) ATP acts as an agonist to promote stimulus-induced secretion of IL-1 beta and IL-18 in human blood. J Immunol 165:46154623

38. Comens PG, Wolf BA, Unanue ER, Lacy PE, McDaniel ML (1987) Interleukin 1 is potent modulator of insulin secretion from isolated rat islets of Langerhans. Diabetes 36:963-970

39. Arnush M, Heitmeier MR, Scarim AL, Marino MH, Manning PT, Corbett JA (1998) IL-1 produced and released endogenously within human islets inhibits beta cell function. J Clin Invest 102:516-526

40. Liu C, Wan X, Ye T et al (2014) Matrix metalloproteinase 2 contributes to pancreatic Beta cell injury induced by oxidative stress. PLoS One 9:e110227

41. Xiao X, Gittes GK (2015) Concise review: new insights into the role of macrophages in $\beta$-cell proliferation. Stem Cells Transl Med 4:655-658

42. Ellingsgaard H, Hauselmann I, Schuler B et al (2011) Interleukin-6 enhances insulin secretion by increasing glucagon-like peptide-1 secretion from L cells and alpha cells. Nat Med 17:1481-1489

43. Chovatiya R, Medzhitov R (2014) Stress, inflammation, and defense of homeostasis. Mol Cell 54:281-288

44. Appels B, Burkart V, Kantwerk-Funke G, Funda J, Kolb-Bachofen V, Kolb H (1989) Spontaneous cytotoxicity of macrophages against pancreatic islet cells. J Immunol 142:3803-3808

45. Burkart V, Kolb H (1996) Macrophages in islet destruction in autoimmune diabetes mellitus. Immunobiology 195:601-613

46. Ferris ST, Carrero JA, Mohan JF, Calderon B, Murphy KM, Unanue ER (2014) A minor subset of Batf3-dependent antigenpresenting cells in islets of Langerhans is essential for the development of autoimmune diabetes. Immunity 41:657-669

47. Hildner K, Edelson BT, Purtha WE et al (2008) Batf3 deficiency reveals a critical role for $\mathrm{CD} 8 \alpha+$ dendritic cells in cytotoxic $\mathrm{T}$ cell immunity. Science 322:1097-1100

48. Jansen A, Homo-Delarche F, Hooijkaas H, Leenen PJ, Dardenne M, Drexhage HA (1994) Immunohistochemical characterization of monocytes-macrophages and dendritic cells involved in the initiation of the insulitis and $\beta$-cell destruction in NOD mice. Diabetes 43:667-675

49. Kolb H, Burkart V, Appels B et al (1990) Essential contribution of macrophages to islet cell destruction in vivo and in vitro. $\mathrm{J}$ Autoimmun 3(Suppl 1):117-120

50. Thornley TB, Agarwal KA, Kyriazis P et al (2016) Contrasting roles of islet resident immunoregulatory macrophages and dendritic cells in experimental autoimmune type 1 diabetes. PLoS One 11: e0150792

51. Vomund AN, Zinselmeyer BH, Hughes J et al (2015) Beta cells transfer vesicles containing insulin to phagocytes for presentation to T cells. Proc Natl Acad Sci U S A 112:E5496-E5502

52. Donath MY, Dalmas E, Sauter NS, Boni-Schnetzler M (2013) Inflammation in obesity and diabetes: islet dysfunction and therapeutic opportunity. Cell Metab 17:860-872

53. Eguchi K, Manabe I (2013) Macrophages and islet inflammation in type 2 diabetes. Diabetes Obes Metab 15(Suppl 3):152-158 